Salma, Nur. (2019). Effect of Capital Adequacy Ration, Non Performing Loan, Third Party Funds on Loan to Deposit Ratio in Private Commercial Banks in Indonesia Stock Exchange. Cendekia (2019), 13(2): 153 164. DOI: 10.30957/cendekia.v13i2.605.

\title{
Effect of Capital Adequacy Ratio, Nonperforming Loan, Third Party Funds on Loan to Deposit Ratio in Private Commercial Banks in Indonesia Stock Exchange
}

\author{
Nur Salma \\ Accounting Study Program, Faculty of Business, \\ University of Mitra Indonesia \\ correspondence: $\underline{\text { salma@umitra.ac.id }}$
}

\begin{abstract}
The study aims to analyze the impact of capital adequacy ratio, non-performing loan, third party fund on loan to deposit ratio of the private banks in Bandar Lampung. Sample used in this research were obtained from six private banks in Bandar Lampung. Data obtained based on financial statements Annual Report of Indonesia stock Exchange (IDX) from 2009 to 2014. The method used in this research is dependent variable and independent, multiple regression analysis and Classical Assumption. Variable used Capital Adequacy Ratio (CAR), Nonperforming Loan (NPL), and Third Party Fund (DPK) on Loan to Deposit Ratio (LDR). Based on the result of the research showed that the $F$ variable CAR, NPL, and DPK together influential significantly to Loan to Deposit Ratio. The Result of partial $\mathrm{T}$ test CAR negatively influential and significant with significant value is 0.007 . NPL is not positively influential and not significant on LDR with significant value is 0,277 while DPK has positive influential and significant value is 0,005 . The value of Adjusted $R$ Square the value is 0.266 showed that LDR can explain by variables research as big as $26,6 \%$, while the rest can be explained by other factors.
\end{abstract}

Keywords: Capital, Nonpperforming, Loan, Deposit, Ratio

\section{INTRODUCTION}

The ratio of Loan to Deposit Ratio is the ratio of the amount of funds channeled to the community (credit) with the amount of public funds and own capital used. According to Sofyan Syafri Harahap (2011), the Loan to Deposit Ratio (LDR) ratio shows how much the loan is given by third party funds. Therefore Indonesian banks have set a standard for the LDR which ranges from $85 \%$ to $100 \%$. Thus if the bank has an LDR that is too low or too high, the bank will find it difficult to increase profits.

Capital is the most important part of a company so that it can survive and operate, including banking companies in channeling funds to the public and banks also need capital. In a banking company, bank capital must be used to maintain the possibility of the risk caused by the credit itself. According to Cashmir (2014), Capital Adequacy Ratio is the ratio used to measure capital and elimination reserves in handling credit, especially the risk of occurring because the interest fails to be collected. Therefore, Bank Indonesia has set a standard that must be achieved by CAR of $8 \%$, with the provision of $4 \%$ core capital (CAR tier 1 ) and $4 \%$ secondary capital (CAR tier 2 ). Thus 
a large capital, a bank can channel more credit. In line with increasing credit, it will increase the LDR itself.

Internal factors that occur in the banking sector as well as external factors that encourage the occurrence of credit risk in the form of non-smooth returns are called non-performing loans (NPLs). Seandy Nanda Dipa (2010), congestion of credit facilities is caused by two factors from the customer's side. Non-performing loans can be measured by their collectibility. Is a percentage of the number of non-performing loans (with criteria for substandard, doubtful and loss) on the total credit issued by the bank. Non-performing loans can cause banks to be reluctant to channel credit because they have to form a large reserve reserve, thereby reducing the amount of credit given by a bank, so that it will affect the LDR ratio to increase. The standard set by Indonesian banks is less than 5\%. Third Party Funds (TPF) is a ratio that can provide information about the ability of banks to cover large bank liabilities quickly (Sofyan Syafri Harahap, 2011). This ratio is very much needed by banking companies in running and maintaining a company, because Third Party Funds will increase credit growth, which eventually also increases LDR.

Table 1.1. Average data on CAR, NPL, DPK and LDR of private Lampung bank companies for the period 2010-2015

\begin{tabular}{|l|l|l|l|l|l|l|l|}
\hline \multirow{2}{*}{ Ratio } & \multicolumn{7}{|c|}{ Year } \\
\cline { 2 - 8 } & 2009 & 2010 & 2011 & 2012 & 2013 & 2014 & mean \\
\hline CAR \% & 9,96 & 10,17 & 107,06 & 101,72 & 111,37 & 121,23 & 77,00 \\
\hline NPL \% & 1.88 & 3,85 & 1,06 & 0,92 & 1,14 & 1,45 & 10,3 \\
\hline DPK \% & 85,43 & 82,36 & 68,89 & 79,5 & 68,8 & 70,18 & 75,86 \\
\hline LDR \% & 105,09 & 121,74 & 83,55 & 85,97 & 87,46 & 93,98 & 96,29 \\
\hline
\end{tabular}

Source: Annual Report IDX (Data processed)

Based on Table 1.1 above, finance calculated from the CAR, NPL, TPF and LDR shows that the average experiences ups and downs, during 2009-2014 the CAR ratio decreased in 2011. NPLs experienced a decline in two consecutive years in 2011 and 2012. While deposits decreased in 2010, 2011 and 2013, and the LDR decreased dramatically in 2011.

Financial ratios calculated ratio Capital Adequacy Ratio has an average of $77.00 \%$ Thus the higher the value of CAR, the better the performance in the company, on the contrary if the value of CAR decreases, the company's performance is not good. Likewise with Nonperforming Loans, if bad credit increases, it will reduce the ability of banks to channel credit. However, this NPL ratio which has increased against the LDR has decreased in 2011-2012 and in 2013-2014 it has increased again. This NPL ratio has an average of $10.3 \%$. Thus the increasing NPL, the performance of the company in channeling its loans was declared not good.

The Third Party Fund Ratio shows the average decline from 2010 - 2011 and 2013, experiencing an increase again in 2012, 2014 and because the greater DPK in collecting funds from the community, the better the performance of companies in the 
company to maintain the company. From 2009 - 2014 Third Party Funds had an average of $75.86 \%$. thus increasing DPK income, the company's performance is declared good.

The Loan to Deposit Ratio has an average of $96.29 \%$. Because the lower the LDR, the lower the company's finances. From 2009 - 2014, the LDR always experienced fluctuactive but in 2011 it experienced a drastic decline of $38 \%$. Thus increasing the LDR further stated that the finance in the company was declared good.

\section{REVIEW OF LITERATURE}

Banks are one of the financial institutions that have a very important role in the country's economic development sector. The role of bank strategy is not only a place that is able to collect and channel community funds effectively and efficiently towards improving people's living standards, but also motivating and encouraging innovation in various branches of economic activity.

Understanding of the Bank according to Republic of Indonesia Law number 10 of 1998 which is intended by the Bank is a business entity that collects funds from the public in the form of savings and distribution of society in the form of loans and / or other forms in order to improve people's lives. It can be concluded that the banking business collects funds, and distributes funds to the community with the aim that with this intermediation, the bank can encourage the improvement of living standards of the people (Budisantoso, 2011).

According to Latumaerissa (2011), a bank is a business entity whose main activities are receiving deposits from the public and / or other parties, then re-allocating them to obtain profits and providing services in payment traffic.

The definition of banks and financial institutions whose main activities are to raise funds from the public and redistribute the funds to the community and provide other bank services (Kasmir, 2014).

\section{METHODS}

The population of the research data were 8 banking companies, and the samples taken were only 6 banking companies. In this research the data used is quantitative data in the form of panel data. The analysis technique used in this study is quantitative analysis. In an effort to discuss the problem used multiple regression analysis tools and classical assumption tests.

\section{RESULTS AND DISCUSSION}

\subsection{Normality Test Results}

Based on the data in table 4.1.2.1, it is known that the number (N) in this study is as many as 36. The number obtained in the observation year is 6 years with the Bank's annual data collection, so the observation in this study becomes $6 \times 6=36$ observations. To normalize the research data using a transformation technique with a natural variable feed to make a normal distribution with a significance level of 0.068 which is above 0.05 which can be concluded that the regression model in this study meets the test of the classical normality assumption 
Table 2. One-Sample Kolmogorov-Smirnov Test

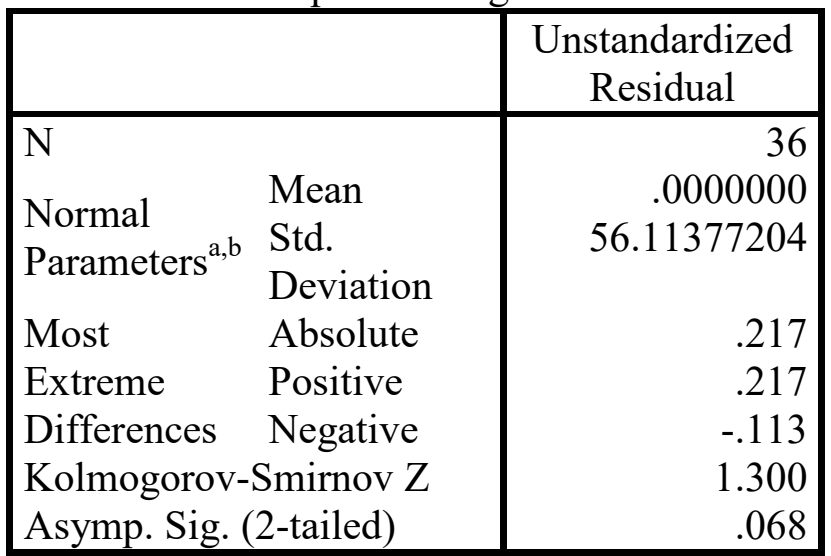

Source: SPSS 21, 2016 output (data processed)

\subsection{Multicollinearity test}

Table 3. Multicollinearity Test Results Coefficients

\begin{tabular}{|c|c|c|c|c|c|c|c|}
\hline \multirow[t]{2}{*}{ Model } & \multicolumn{2}{|c|}{$\begin{array}{r}\text { Unstandardized } \\
\text { Coefficients }\end{array}$} & \multirow{2}{*}{\begin{tabular}{|r}
$\begin{array}{r}\text { andardized } \\
\text { Coefficie } \\
\text { nts }\end{array}$ \\
Beta
\end{tabular}} & \multirow[t]{2}{*}{$\mathrm{T}$} & \multirow[t]{2}{*}{ Sig. } & \multicolumn{2}{|c|}{$\begin{array}{l}\text { Collinearity } \\
\text { Statistics }\end{array}$} \\
\hline & B & $\begin{array}{l}\text { Std. } \\
\text { Error }\end{array}$ & & & & olerance & VIF \\
\hline (Constant & -84.729 & $\$ 3.527$ & & -1.583 & 123 & & \\
\hline CAR & -2.374 & .817 & -.554 & -2.906 & 007 & .576 & 1.735 \\
\hline NPL & 11.228 & 0.163 & .169 & 1.105 & 277 & .899 & 1.113 \\
\hline DPK & 2.463 & .752 & .649 & 3.275 & 003 & .533 & 1.875 \\
\hline
\end{tabular}

Source: SPSS 21, 2016 output (data processed)

Based on table 4.1.2.2 Variance Inflation Factor (VIF) and tolerance, if VIF exceeds 10 or tolerance is less than 0.10 , and then there are symptoms of multi collinearity. Conversely, if VIF and tolerance are more than 0.10 , it is stated that there is no multi collinearity.

1. VIF value CAR variable is $1.735<10$ and tolerance value is $0.576>0.10$ so that CAR is declared to have no multicollinearity.

2. The VPL value of the NPL variable is $1.113<10$ and the tolerance value is $0.899>$ 0.10 so that the NPL is stated to have no multicollinearity.

3. Variable VIF value of TPF is $1.875<10$ and tolerance score is $0.533>0.10$ so DPK is declared to have no multicollinearity.

Based on Table 4.1.2.2 shows that CAR, NPL, and TPF have tolerance values> 0.10 and VIF values $<10$. This can be concluded that the independent variables used in this research regression model do not occur multicollinearity. 


\subsection{Test autocorrelation}

Table 4. Autocorrelation Test Model Summary

\begin{tabular}{|l|r|c|c|c|c|}
\hline $\begin{array}{l}\text { M } \\
\text { od } \\
\text { el }\end{array}$ & R & $\begin{array}{c}\text { R } \\
\text { Sq } \\
\text { uar } \\
\text { e }\end{array}$ & $\begin{array}{c}\text { Adj } \\
\text { uste } \\
\text { d R } \\
\text { Squ } \\
\text { are }\end{array}$ & $\begin{array}{c}\text { Std. } \\
\text { Error of } \\
\text { the } \\
\text { Estimat } \\
\text { e }\end{array}$ & $\begin{array}{c}\text { Dur } \\
\text { bin- } \\
\text { Wat } \\
\text { son }\end{array}$ \\
\hline 1 & $\begin{array}{r}.5 \\
73\end{array}$ & $\begin{array}{r}.32 \\
\text { a }\end{array}$ & .266 & 58.6851 & .775 \\
& & 9 & \\
\hline
\end{tabular}

a. Predictors: (Constant), DPK, NPL, CAR

b. Dependent Variable: LDR

Source: SPSS 21, 2016 output (data processed)

Based on the results of the auto correlation test can be seen in table 4.1.2.3 above it can be seen that the Durbin-Watson value for this study amounted to 0.775 above $\mathrm{R}$ 0.573 , then this study did not occur auto correlation.

\subsection{Hetero scedasticity test}

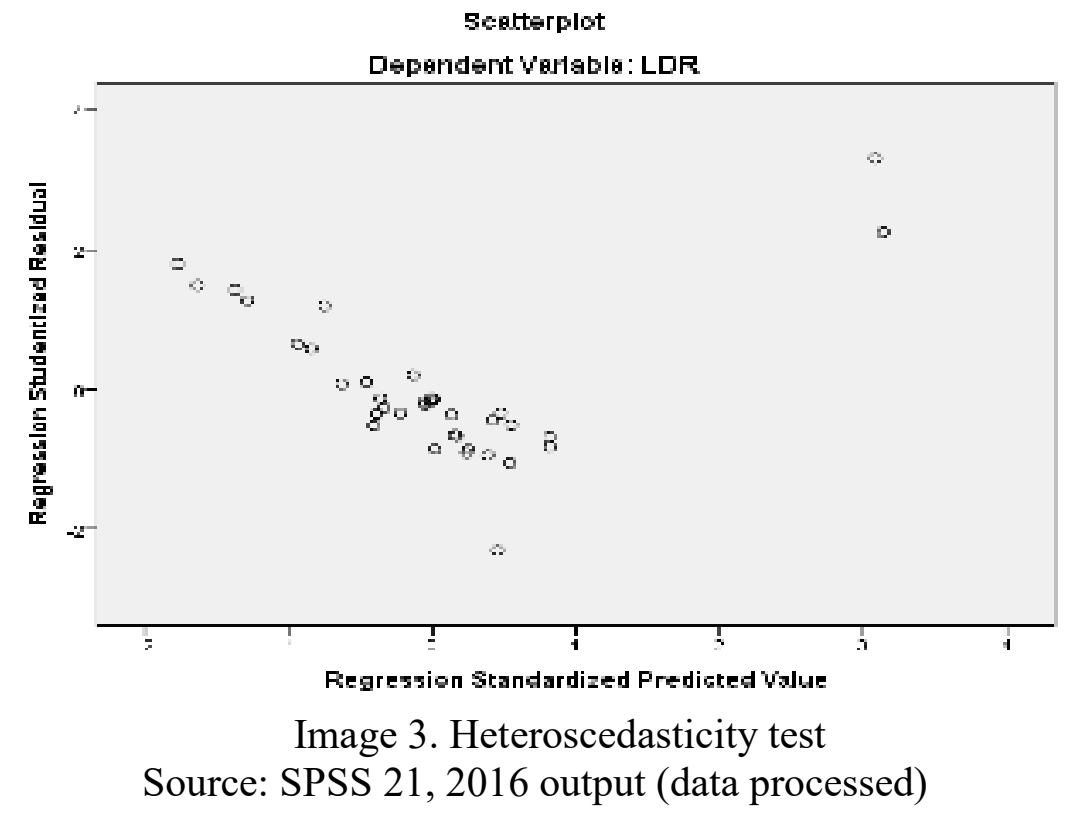

Based on Figure 4.3 from the output above, it can be seen that the points do not form a clear pattern. The points spread above 0 on the $\mathrm{Y}$ axis. So it can be concluded 
that in the Heteroscedasticity test there is no Heteroscedasticity problem in the regression model.

\subsection{Multiple Regression Test}

Table 5. of Results of Regression Analysis of Coefficient

\begin{tabular}{|c|c|c|c|c|c|c|c|}
\hline \multirow[t]{2}{*}{ Model } & \multicolumn{2}{|c|}{$\begin{array}{r}\text { Unstandardized } \\
\text { Coefficients }\end{array}$} & \multirow{2}{*}{\begin{tabular}{|r|r}
$\begin{array}{r}\text { andardized } \\
\text { Coefficie } \\
\text { nts }\end{array}$ \\
Beta
\end{tabular}} & \multirow[t]{2}{*}{$\mathrm{T}$} & \multirow[t]{2}{*}{ Sig. } & \multicolumn{2}{|c|}{$\begin{array}{l}\text { Collinearity } \\
\text { Statistics }\end{array}$} \\
\hline & B & $\begin{array}{l}\text { Std. } \\
\text { Error }\end{array}$ & & & & olerance & VIF \\
\hline Constant) & -84.729 & 53.527 & & -1.583 & 123 & & \\
\hline CAR & -2.374 & .817 & -.554 & -2.906 & 007 & .576 & 1.735 \\
\hline NPL & 11.228 & 0.163 & .169 & 1.105 & 277 & .899 & 1.113 \\
\hline $\mathrm{PK}$ & 2.463 & .752 & .649 & 3.275 & 003 & .533 & 1.875 \\
\hline
\end{tabular}

Source: SPSS 21, 2016 output (data processed)

Based on table 5 above, it can be seen that the value of a constant is -0.84 .729$ and the regression coefficient $\mathrm{b} 1-0.2 .374, \mathrm{~b} 2-0.11 .228, \mathrm{~b} 3-0.2 .463$ Value constants and regression coefficients $(\mathrm{a}, \mathrm{b} 1, \mathrm{~b} 2, \mathrm{~b} 3)$ this is included in the following multiple liner regression equation:

$$
\begin{aligned}
& \mathrm{Y}=\mathrm{a}+\mathrm{b} 1 \mathrm{X} 1+\mathrm{b} 2 \mathrm{X} 2+\mathrm{b} 3 \mathrm{X} 3+\mathrm{e} \\
& \text { So the regression equation is as follows: } \\
& \mathrm{Y}=-84.729-0,2,374 \mathrm{X} 1+0,11,228 \mathrm{X} 2+\mathrm{O}, 2,463 \mathrm{X} 3
\end{aligned}
$$

From the multiple linear equations above, it can be seen the constants value of 0, 84,729 means if X1 (CAR), X2 (NPL), X3 (DPK).

\begin{tabular}{|c|c|c|c|c|c|}
\hline $\begin{array}{l}\text { Mo } \\
\text { del }\end{array}$ & $\mathrm{R}$ & $\begin{array}{c}\mathrm{R} \\
\text { Squ } \\
\text { are }\end{array}$ & $\begin{array}{l}\text { Adju } \\
\text { sted } \\
\text { R } \\
\text { Squa } \\
\text { re }\end{array}$ & $\begin{array}{c}\text { Std. } \\
\text { Error } \\
\text { of the } \\
\text { Esti } \\
\text { mate }\end{array}$ & $\begin{array}{l}\text { Dur } \\
\text { bin- } \\
\text { Wat } \\
\text { son }\end{array}$ \\
\hline 1 & $.573^{\mathrm{a}}$ & 329 & .266 & $\begin{array}{r}58.68 \\
519\end{array}$ & .775 \\
\hline
\end{tabular}

\subsection{Hypothesis testing}

Table 6. of Result of Calculation of Termination Coefficient (R2)

a. Predictors: (Constant), DPK, NPL,

CAR

b. Dependent Variable: LDR

Source: SPSS 21, 2016 (Data processed)

Based on the SPSS output above, it can be seen that from the calculation results obtained the value (R2) of 0.266 . In other words this shows that the percentage variation of Loan to Deposit Ratio (LDR) which can be explained by variations of the four 
Salma, Nur. (2019). Effect of Capital Adequacy Ration, Non Performing Loan, Third Party Funds on Loan to Deposit Ratio in Private Commercial Banks in Indonesia Stock Exchange. Cendekia (2019), 13(2): 153 164. DOI: 10.30957/cendekia.v13i2.605.

independent variables namely CAR, NPL and DPK is $27 \%$ while the rest is influenced by other variables outside the research variable

Table 7. of Results of F (Simultaneous) Test of Analysis of Variance (Anova) F Coefficient

\begin{tabular}{|l|r|r|r|r|r|}
\hline Model & $\begin{array}{c}\text { Sum of } \\
\text { Squares }\end{array}$ & $\begin{array}{c}\text { Degre } \\
\text { e of } \\
\text { freedo } \\
\mathrm{m}\end{array}$ & $\begin{array}{c}\text { Mean } \\
\text { Square }\end{array}$ & F & Sig. \\
\hline $\begin{array}{l}\text { Regressi } \\
\text { on }\end{array}$ & 53980.779 & 3 & 17993.5 & 5.22 & $.005^{\mathrm{b}}$ \\
Residual & $\begin{array}{r}110206.43 \\
9\end{array}$ & 32 & 3443.95 & 5 & \\
Total & $\begin{array}{r}164187.21 \\
8\end{array}$ & 35 & & & \\
\hline
\end{tabular}

a. Dependent Variable: LDR

b. Predictors: (Constant), DPK, NPL, CAR

Source: SPSS 21, 2016 output (data processed)

In table 7 , it can be concluded that the F test results show $F$ count value of 3.338 with a significance value (sig) of 0.031 because the significance value is smaller than $0.05(0.005<0.05)$ and the calculated $F$ value $>F$ table $(5.225>2.90)$. this shows that the CAR, NPL, TPF variables jointly affect the LDR. So that the hypothesis which states CAR, NPL, DPK has an effect on the LDR can be accepted.

\subsection{Partial Test Results (t count)}

\begin{tabular}{|c|c|c|c|c|c|c|c|c|}
\hline \multirow{2}{*}{\multicolumn{2}{|c|}{ Model }} & \multicolumn{2}{|c|}{$\begin{array}{c}\text { Unstandardized } \\
\text { Coefficients }\end{array}$} & \multirow{2}{*}{$\begin{array}{c}\text { Standardi } \\
\text { zed } \\
\text { Coefficie } \\
\text { nts } \\
\text { Beta }\end{array}$} & \multirow[t]{2}{*}{$\mathrm{t}$} & \multirow[t]{2}{*}{ Sig. } & \multicolumn{2}{|c|}{ Collinearity Statistics } \\
\hline & & $\mathrm{B}$ & $\begin{array}{l}\text { Std. } \\
\text { Error }\end{array}$ & & & & Tolerance & VIF \\
\hline \multirow{4}{*}{1} & $\begin{array}{l}\text { (Constan } \\
\text { t) }\end{array}$ & $\begin{array}{r}- \\
84.72 \\
9\end{array}$ & 53.527 & & 1.583 & .123 & & \\
\hline & CAR & 2.374 & .817 & -.554 & 2.906 & .007 & .576 & 1.735 \\
\hline & NPL & $\begin{array}{r}11.22 \\
8\end{array}$ & 10.163 & .169 & 1.105 & .277 & .899 & 1.113 \\
\hline & DPK & 2.463 & .752 & .649 & 3.275 & .003 & .533 & 1.875 \\
\hline
\end{tabular}

a. Dependent Variable: LDR 
Source: SPSS 21, 2016 (data processed)

From table 4.1.3.2 above, the results of multiple regression can analyze the effect of each variable CAR, NPL, TPF on the LDR can be seen from a significant level. The CAR variable has a negative direction, while the NPL and DPK variables show a positive direction, of the three variables CAR and DPP NPL which have a significant effect on the LDR because the sig value is smaller than 0.05 , while the NPL variable does not significantly influence because the sig value is greater than 0.05 . follows:

The hypothesis proposed in this study can have a positive or negative effect as

1. CAR variable has a value of $t$-count of -2.906 while $t$ table is 1.69389 because the value of tcount $>$ ttable value $(-2.906>1.69389)$ and significance value $0.007>0.05$ indicates a significant value. Then it can be concluded that CAR has a negative effect on LDR. Thus the higher the CAR value, the better the performance in the company, and vice versa if the CAR value decreases, the company's performance is considered not good. So, the initial hypothesis proposed, namely: Capital Adequacy Ratio (CAR) has a positive effect on the Loan to Deposit Ratio (LDR) of banking companies listed on the 2009-2014 IDX proide rejected because the CAR value has a negative effect.

2. The NPL variable has a tcount of 1.105 while the t table is 1.69389 because the tcount $<$ ttable value $(1.105<1.69389)$ and the significance value of $0.277>0.05$ indicates a non-significance value. So it can be concluded that the NPL has no influence on the LDR positively and not significantly. Thus the increasing NPL, the performance of the company in distributing loans was declared ineffective. So, the initial hypothesis proposed, namely: Non-Perporming Loan (NPL) has a negative effect on the loan to deposit ratio (LDR) of banking companies listed on the 20092014 IDX proide rejected because the sig value is $>0.05$.

3. DPK variable has a value of tcount of 3.275 while $t$ table is 1.69389 because the value of tcount $>$ ttable value $(3.275>1.69389)$ and significance value $0.003<0.05$. Then it can be concluded that TPF affects the LDR positively and significantly. Thus the increase in DPK income, the company's performance is declared good. So, the initial hypothesis proposed is: Third Party Funds (TPF) have a positive effect on the Loan to Deposit Ratio (LDR) of banking companies listed on the 2009-2014 IDX proide received because of the sig value $<0.05$.

\section{DISCUSSION}

\subsection{Test the Hypothesis of the effect of Capital Adequacy Ratio (X1) on the Loan to Deposit Ratio}

From the research conducted, the results of this study indicate that the effect of Capital Adequacy Ratio (CAR) on the Loan to Deposit Ratio (LDR) partially obtained a significance value of 0.007 because the sig value is $<0.05$ and the t-value is $-2.906>$ 1.69389, then the CAR hypothesis has a partial effect on the LDR, because the sig value is smaller than 0.05. this identifies that changes that occur in the CAR have a significant effect on the LDR. It can be seen that the capital ratio shows the ability of the banking 
company to provide funds for the need to operate the company and accommodate the possible risk of losses caused by the bank's operations. Because the greater the capital ratio, the better the capital position. And in the LDR that is too high or low it indicates that the bank is difficult to make a profit. thus in line with the increase in capital, the LDR itself will increase.

Capital Adequacy Ratio (CAR) is a capital adequacy ratio that shows how far all bank activities contain risks where the CAR ratio compares between capital and weighted assets (RWA). capital adequacy should increase capital and reduce interest to minimize the risk of loss in the banking company.

Based on the explanation above the CAR ratio in Private Banks in this study is not good because it is still not minimal in controlling the capital adequacy ratio (CAR) of Private Banks listed on the Indonesia Stock Exchange.

\subsection{Test the Hypothesis of the effect of Non Perporming Loan (X2) on the Loan to Deposit Ratio (Y)}

From the analysis carried out, the results showed that the influence of NonPerporming Loans (NPL) on the Loan to Deposit Ratio (LDR) partially obtained a significance value of 0.277 because the sig value $>0.05$ and the calculated t value of $1.105<1.69389$, the NPL hypothesis does not have a partial effect on the LDR, because the sig value is greater than 0.05. this indicates that changes in the NPL have a significant effect on the LDR. If the NPL is compared with the previous hypothesis, NPL is very contradictory, and the previous hypothesis of NPL has a significant negative effect whereas the current researcher has a positive and insignificant effect on the LDR. The trigger for the difference in the current hypothesis with the previous hypothesis research is due to several factors, namely from the different periods of research, the number of population and samples studied, and the object of the study also different from before. Where the Non Perporming Loan (NPL) is the percentage of the number of non-performing loans (with criteria for substandard, doubtful, and nonperforming) on the total credit issued by the bank.

Non-performing loans can lead to bank reluctance to channel loans because they have to form large elimination reserves, thereby reducing the amount of credit given by a bank, so that it will affect the LDR ratio to increase.

1. Based on the explanation above, the NPL ratio in Private Banks in the study was good because it showed a positive but significant result on a Private Bank listed on the Indonesia Stock Exchange.

2. Test the Hypothesis of the influence of Third Party Funds (X3) on the Loan to Deposit Ratio (Y)

3. The results showed that the influence of Third Party Funds (TPF) on the Loan to Deposit Ratio (LDR) partially obtained a significance value of 0.003 because the value of sig $<0.05$ and the value of t count was $3.275<1.69389$, then the DPK hypothesis had a partial effect on LDR, because the sig value is smaller than 0.05. this identifies that there is no change with the previous hypothesis. It is known that Third Party Funds (TPF) are ratios that can provide information about the ability of banks to cover large bank obligations quickly. So the more DPK income increases, 
the company's performance is declared good. Where the ratio of deposits is a ratio that is needed by banking companies in carrying out and maintaining a company, because Third Party Funds are deposits from the public. That way the bank can utilize funds from these third parties to be placed in posts that generate income for the bank. So, if third party funds get a lot of savings from the community, this will result in credit growth which in the end the LDR will also increase.

4. Based on the explanation above the DPK ratio in Private Banks in this study is already good because the results show a positive and significant direction on the Private Banks listed on the IDX.

5. 2. Test the Hypothesis of the effect of CAR (X1), NPL (X2), DPK (X3) on the Loan to Deposit Ratio (Y)

6. The results showed that the effect of CAR, NPL, TPF on LDR simultaneously obtained a significant value of 0.005 because the value of sig $<0.05(0.005<0.05)$ and $F$ count $>F$ table $(5.225>2.90)$. So the CAR, NPL, DPK hypothesis has a joint effect on the LDR.

\section{CONCLUSION}

Based on the results of the data analysis described in the previous discussion, the conclusions of this study are as follows:

1. The effect of CAR on LDR partially has a negative and significant effect. This is evidenced by the value of tcount $<\mathrm{t}$ table $(-2.906>1.69389)$ and the significance value of $0.007<0.05$ indicates a significant value.

2. Partial effect of NPL on LDR has no positive and insignificant influence. This is evidenced by the value of tcount $<$ ttable $(1.105>1.69389)$ and the significance value of $0.277>0.05$ indicates a non-significant value.

3. The effect of TPF on LDR partially has a positive and significant effect. This is evidenced by the value of tcount $>t$ table $(3.275>1.69389)$ and a significant value of $0.005<0.05$ indicating a significant value.

4. Effect of CAR, NPL, TPF on LDR influences together or simultaneously. This is evidenced by the value of $F$ count $>F$ table $(5.225>2.90)$ and the significance value of $0.005<0.05$.

\section{SUGGESTIONS}

Based on the results of data analysis that has been explained in the previous discussion, the suggestions for this research are as follows:

1. Based on the $t$ test CAR has a negative and significant effect on the LDR. So Ha is accepted. The results of this study are different from the previous hypothesis, the researcher's hypothesis has a significant negative effect on the LDR. That way the company must be able to maintain CAR's financial performance so that the company remains stable. More and more banks are giving credit. RWA also increased. One of the things that can be done by a bank is by increasing capital in order to maintain the risk.

2. Based on $t$ test. NPL is not a positive and not significant effect on the LDR. So Ha is rejected. This result is compared with the opposite hypothesis, the previous 
hypothesis has a significant negative effect on the LDR. According to Dendawijya (2009), NPLs that are too high can reduce a bank's ability to channel credit. In the banking world, it cannot be separated from the name of bad credit, but this can be minimized. For banks, they should be more strict in carrying out the principles before giving credit.

3. Based on the t test. Deposits have a positive and significant effect on the LDR. So Ha is accepted and Ho is rejected. Banking companies are expected to increase their search for deposits. Because giving credit is also the main goal of the bank. One way to increase DPK is to provide attractive interest rates.

\section{LIMITATIONS}

1. The observation period in this study is quite short, from 2009 - 2014 and the data uses annual reports. It is expected that future researchers can use a long period of 8-10 years and data in the form of quarterly financial statements may be able to obtain better predictive results.

2. The author only conducts research on private banking companies listed on the Indonesian Stock Exchange (BEI) Lampung branch so that the results are not necessarily the same if research is carried out directly into a private banking company is completed.

\section{REFERENCES}

Atamaja, L.S. 2012. Research method. Tanggerang: Jelajah Nusantara

Dipa, S.N. 2010. Analysis of the effect of CAR, NPL, Inflation, growth in deposits and exchange against the LDR. Ponogoro: FE Universitas Ponorogo

Fahmi, I. 2012. Analysis of financial performance. Bandung : Alfabera

Firdaus, A. M. 2012. Research method. Tanggerang Selatan: Jelajah Nusantara

Harahap, S.S. 2011. Critical Analysis of Financial Statements. Jakarta: Rajawali Pers

Herman, D. 2011. Banking Management.. Jakarta: Bumi Aksara.

Julius, 2012. Banks and Other Financial Institutions. Jakarta: Salemba Empat.

Kasmir, 2011. Banking Management. Jakarta: Salemba Empat.

Kasmir, 2014. Analysis of Financial Statements.. Jakarta: Raja Grafindo Persada.

Kurniawan, B. 2012. Research method. Tanggerang: Jelajah Nusantara

Lukman, D.W. 2009. Banking Management. Bogor: Ghalia Indonesia.

Lyvia, C. 2012. nalysis of Deposits, LDR, CAR, NPL, Against the Volume of Banking Loans. Lampung: Universitas Bandar Lampung, Fakultas Ekonomi dan Bisnis.

Malayu, H. 2011. Banking basics. Jakarta: Bumi Aksara.

Munawir, S. 2010. Analysis of financial statements.. Yogyakarta: Liberty 
CENDEKIA, Vol. 13 No. 2 Oktober 2019

p ISSN: 1978 2098; e ISSN: 2407 8557

Https://soloclcs.org; Email: cendekiaoslo@gmail.com

Center of Language and Cultural Studies, Surakarta, Indonesia

Salma, Nur. (2019). Effect of Capital Adequacy Ration, Non Performing Loan, Third Party Funds on Loan to Deposit Ratio in Private Commercial Banks in Indonesia Stock Exchange. Cendekia (2019), 13(2): 153 164. DOI: 10.30957/cendekia.v13i2.605.

Prayitno, A. 2014. Analysis of the effect of CAR, OEOR and ROA on profit growth. Lampung: STIE Mitra Lampung

Priyatno, D. 2012. How to lighten data analysis with SPSS 20.. Yogyakarta: Andy

Purwanto, S. 2011. Statistics for Modern Financial Economics. Jakarta: Salemba Empat.

Santoso, B.T. 2012. Banks and Other Financial Institutions, Jakarta Selatan: Salemba Empat.

Sanusi, A. 2014. Business Research Methodology. Jakarta: Salemba Empat.

Siswanto, A. V. 2012. Strategies and Research Steps. Yogyakarta: Graha Ilmu.

Yuslinda, E. 2012. Effect of DPK, CAR, FDR, NPF on profitability. Lampung: IBI Darmajaya Fakultas Ekonomi Akuntansi

Zaki, B. 2012. Intermediate accounting. Yogyakarta: BPFE. 